УДК 597.2/.5:57.063.7(282.247.133.5)»321"

doi: $10.31140 /$ j.vestnikib.2020.1(212).2

\title{
СТРУКТУРА РЫБНОГО НАСЕЛЕНИЯ ПОЙМЫ СРЕДНЕГО ТЕЧЕНИЯ РЕКИ СЫСОЛЫ В ПЕРИОД ВЕСЕННЕГО ПОЛОВОДЬЯ
}

\author{
В.И. Пономарев, Н.П. Соколова \\ Институт биологии Коми научного центра Уральского отделения Российской академии наук, Сыктывкар \\ E-mail: ponomarev@ib.komisc.ru
}

\begin{abstract}
Аннотация. В работе приведены результаты впервые предпринятого ихтиофаунистического обследования придаточных водоемов и участков поймы среднего течения р. Сысолы, залитых водой в период весеннего половодья. Охарактеризована структура местного рыбного населения. Выявлено обитание здесь 11 видов рыб: щуки, леща, уклейки, густеры, золотого карася, голавля, язя, ельца, плотвы, налима и окуня. Ряд видов рыб использует пойму для нереста и нагула. Представлены биологические показатели массовых видов рыб и охарактеризованы некоторые особенности их биологии.
\end{abstract}

Ключевые слова: Сысола, пойма, придаточные водоемы, рыбное население, разнообразие, биологические показатели

\section{Введение}

Сысола - один из двух (наряду с р. Вымь) крупнейших притоков р. Вычегды. Ее длина составляет 487 км, а водосборная площадь - 17200 км $^{2}$ (Ресурсы ..., 1972). В бассейне этого водотока расположено 374 озера общей площадью $19.1 \mathrm{kм}^{2}$. Сысола принимает около 50 притоков, среди них крупнейшие: Воктым, Тыбъю, Большая Визинга (левые); Ныдыб, Лэпъю, Поинга (правые).

Несмотря на наличие специализированных научных и научно-практических учреждений в г. Сыктывкаре и развитость сети автодорог, ихтиофауна и рыбное население Сысолы остаются практически не изученными. В литературе отсутствует даже общий список обитающих здесь рыб. Исследователи разных поколений ограничивались перечнем общего состава видов рыб бассейна p. Вычегды (Зверева, 1955; Соловкина, 1975; Бознак, 2003), дополненного впоследствии списком ихтиофауны бассейна р. Вымь (Захаров, 2019).

Непосредственно изучению ихтиофауны водоемов бассейна р. Сысолы посвящено лишь две работы. В первой из них (Кадастр ..., 2014) приведены результаты ихтиофаунистического обследования к.б.н. А.Б. Захаровым ряда пойменных водоемов и притоков р. Сысолы (в рамках предпринятой Минприроды Республики Коми и Институтом биологии Коми НЦ УрО РАН инвентаризации особо охраняемых природных территорий). Эти водные объекты расположены в границах ихтиологических заказников "Визингский», «Каджеромский», «Абкеджский», водных памятников природы «Гарсибский», «Озеро Вадыб-ты» и «Водохранилище Кажимское». В этой же работе охарактеризовано рыбное население Нювчимского водохранилища и р. Нювчим. Всего в бассейне р. Сысолы отмечено 19 видов рыб: стерлядь, сиг, хариус, щука, лещ, белоглазка, густеpa, пескарь, верховка, язь, елец, обыкновенный гольян, плотва, золотой карась, голец усатый, налим, ерш, окунь и подкаменщик.
В публикации P.P. Рафикова с соавторами (2015) приведены сведения о видовом составе рыб Нювчимского и Кажимского водохранилищ и формирующих их малых рек Нювчим и Кажим. Списочный состав включает 14 видов; по сравнению с предыдущим перечнем здесь отсутствуют стерлядь, лещ, белоглазка, густера и золотой карась.

Таким образом, для ученых сохраняются обширные перспективы исследований как состава ихтиофауны магистрального русла р. Сысолы, ее притоков и придаточных водоемов, так и различных аспектов биологии и экологии обитающих здесь рыб.

Данная работа нацелена на изучение структуры рыбного населения постоянных и временных пойменных водоемов в период весеннего половодья на примере участка водосбора р. Сысолы в районе с. Ыб (Сыктывдинский район Республики Коми).

\section{Материалы и методы}

Сбор и лабораторную обработку ихтиологических материалов выполнили в 2015-2019 гг. в соответствии с классическими методами исследований (Правдин, 1966). Детальное расположение изученных водоемов в пределах района исследований представлено на рис. 1.

Отлов рыбы вели ставными жаберными сетями с ячеей $10,20,30,40,50$ и 60 мм, длиной 30 м и высотой 1.8 м. Регистрировали вид используемых в каждом конкретном случае рыболовных снастей, дату, время, величину и состав уловов. У свежепойманных рыб измеряли промысловую длину, определяли общую массу тела, пол и степень половой зрелости. Относительную плотность рыб оценивали при помощи показателя индексной оценки плотности рыб из расчета среднего количества отловленных за единицу времени и на единицу рыболовного усилия экземпляров (экз./ус.ч). Возраст определяли по чешуе. 
Для оценки уровня видового разнообразия использовали следующие индексы: вероятность межвидовых встреч PIE $=1-\Sigma \mathrm{p} 2(\mathrm{i})$, модифицированный индекс Симпсона $S=(\Sigma[\mathrm{p} 2(\mathrm{i})])-1$, индекс Животовского $\mathrm{Sg}=[\Sigma \sqrt{ } \mathrm{p}(\mathrm{i})] 2$, информационная мера Шеннона $\mathrm{H}=-\Sigma \mathrm{p}(\mathrm{i}) \operatorname{lgp}(\mathrm{i})$, индекс Шелдона $\mathrm{SH}=$ $\exp (\mathrm{H})$ (Терещенко, 1994).

\section{Результаты и обсуждение}

В результате впервые проведенного в мае 2015 г. обследования состава рыбного населения поймы, залитой в период весеннего половодья, установлено обитание здесь в это время года 10 видов рыб (рис. 2). При этом списочный состав не оставался постоянным и существенно зависел от уровня воды и его изменения. Во время подъема уровня воды доминировали плотва и уклейка, в контрольных уловах отсутствовали щука, язь и елец, которые появились позже, при спаде уровня воды. В это время уже преобладали густера, плотва и окунь; в уловах не отмечены лещ, уклейка и золотой карась.

Весьма существенно (в 12 раз) снизилась величина относительной плотности плотвы и уклейки (с 1.52 экз./ус.ч до 0), тогда как соответствующие показатели для густеры и окуня, напротив, возросли в 1.5-2.0 раза (рис. 3). Плотность популяций остальных выявленных видов рыб оставалась невысокой по сравнению с видами-доминантами.

Обращает на себя внимание некоторое возрастание уровня разнообразия рыбной части водно-

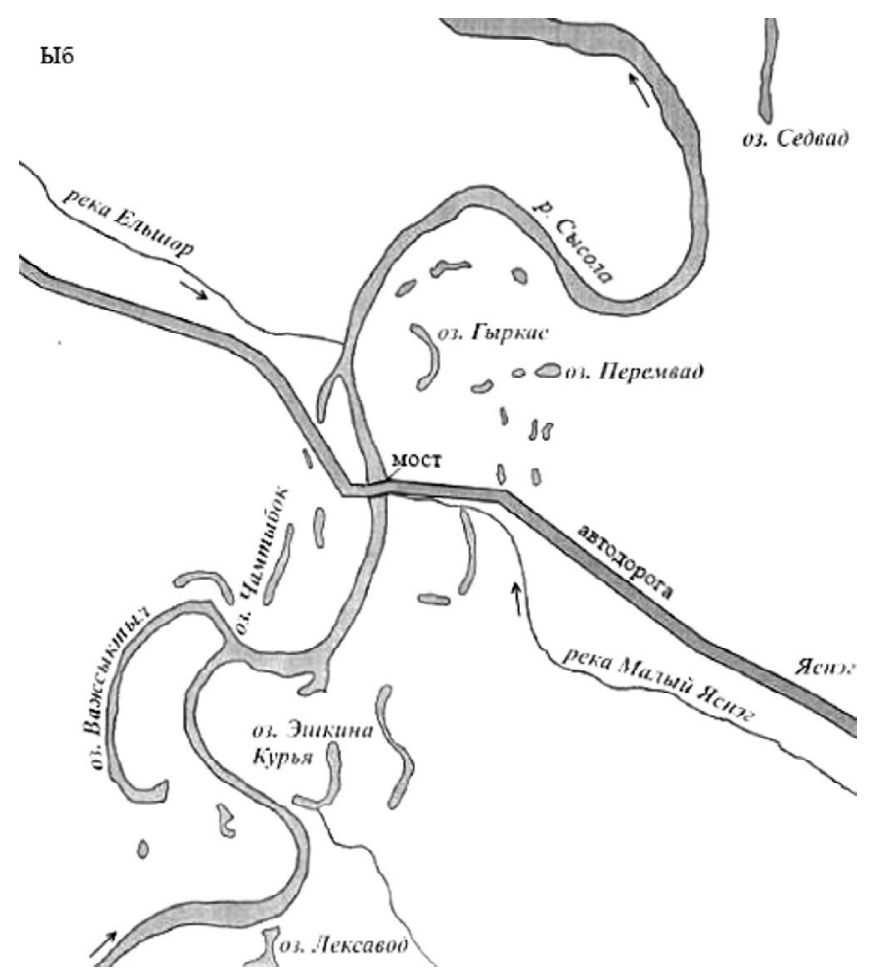

Рис. 1. Карта-схема участка поймы р. Сысолы в районе устья р. Малый Яснэг. го сообщества в период понижения уровня воды (рис. 4), несмотря на то, что общее число видов рыб оставалось без изменений (семь видов в оба сравниваемых периода).

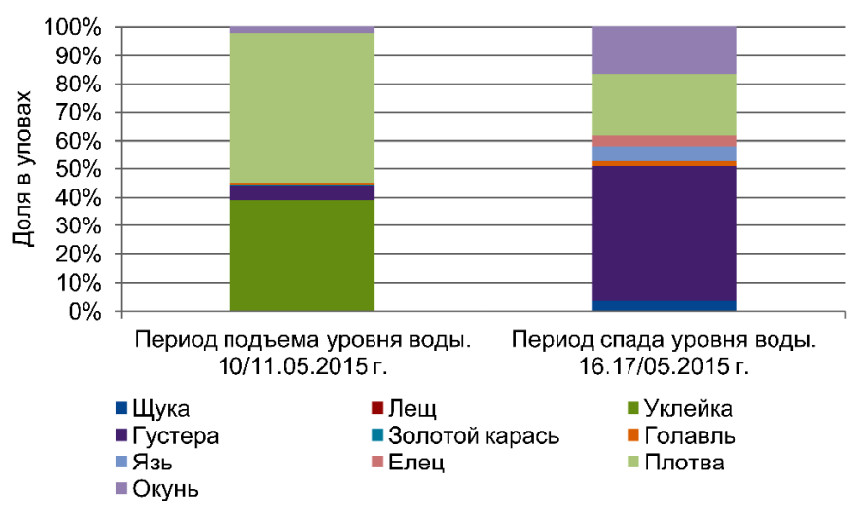

Рис. 2. Состав уловов рыбы на залитых водой лугах в районе курьи Важсыктыл. Стандартный ряд сетей яч. 1060 мм.

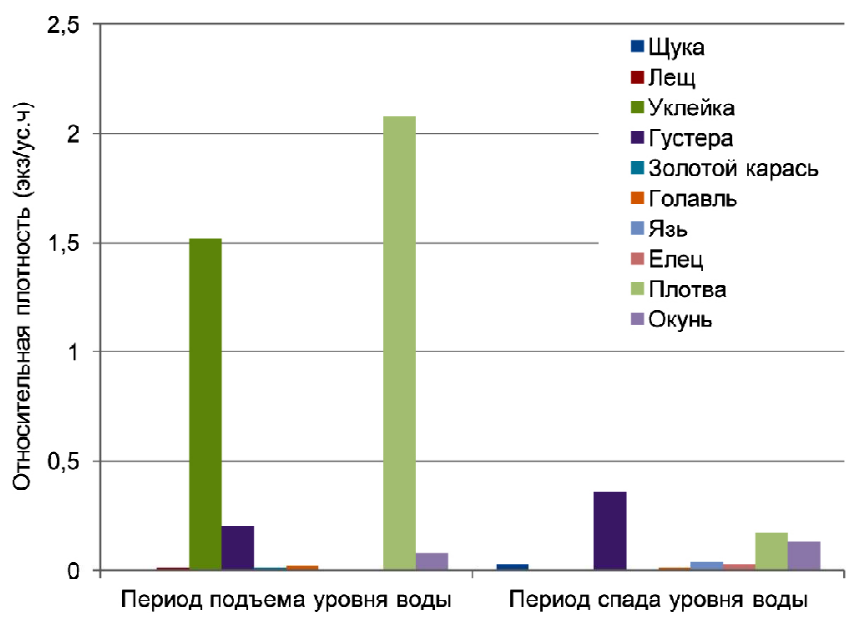

Рис. 3. Относительная плотность рыб на заливных лугах в районе курьи Важсыктыл.

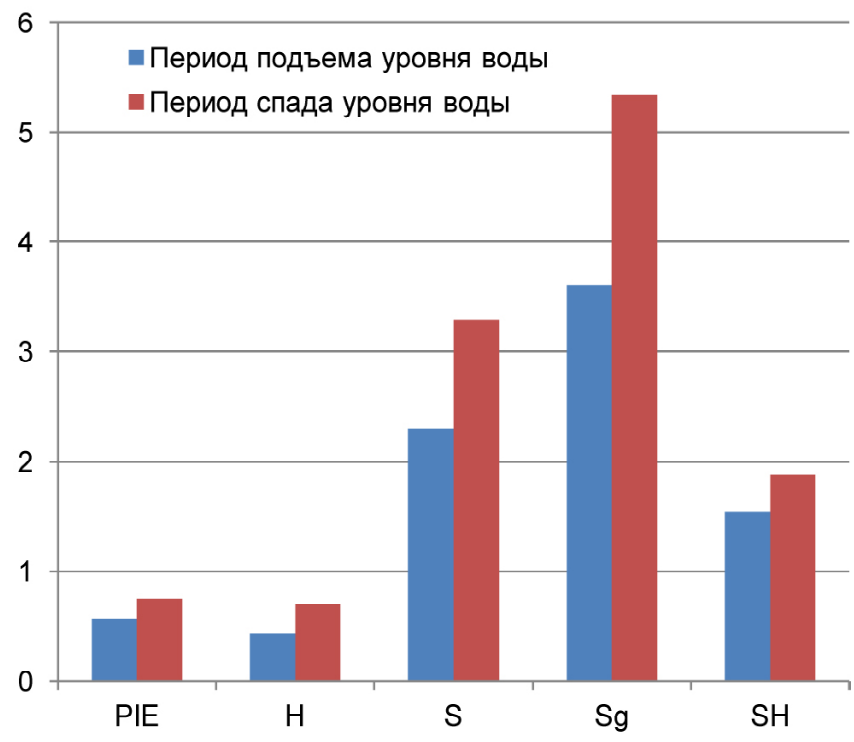

Рис. 4. Величина индексов разнообразия рыбного населения на залитых водой лугах в районе курьи Важсыктыл. 
Состав рыбного населения изменчив и в период максимального уровня воды в весеннее половодье. Действительно, в таких условиях и на тех же залитых водой лугах в районе курьи Важсыктыл число выявленных видов рыб может существенно варьировать (рис. 5). Чаще всего доминантом остается плотва, субдоминантом - густера (или уклейка). На состав рыбного населения серьезное влияние оказывает идущий здесь нерест тех или иных видов рыб. В частности, в начале третьей декады 2018 г. происходил нерест леща, что и сказалось на результатах контрольных уловов. В других случаях речь может идти о нересте густеры и плотвы, икрометание которых также проходит на заливных лугах.

Выраженные различия связаны и с использованием в качестве модельных различных участков залитой водой поймы. Так, в отличие от окрестностей курьи Важсыктыл, пойма в окрестностях безымянной курьи в районе дислокации понтонного автомобильного моста через р. Сысолу характеризуется доминированием в составе уловов ельца. Плотва и уклейка выступают здесь в качестве субдоминантов. При этом относительная плотность большинства видов рыб этого участка поймы, за исключением ельца, значительно уступает таковой на пойменных заливных лугах в районе курьи Важсыктыл (рис. 6). Максимальная плотность отмечена для плотвы и уклейки. Промежуточное положение занимают значения плотности популяции леща в период его нереста.

На первый взгляд, несколько диссонируют с плотностными характеристиками значения индексов разноообразия (рис. 7), особенно при сопоставлении двух различных участков поймы. Разнообразие рыбной части сообщества оказывается выше на участке в районе автомобильного моста, где величина показателей существенно уступает таковым в районе курьи Важсыктыл. На самом деле это объяснимо значительно большей равновзвешенностью доли тех или иных видов рыб на залитых водой лугах у безымянной курьи.
Известным своеобразием отличается состав рыбного населения практически всех обследованных нами в избранном районе исследований постоянных пойменных водоемов (курий и озер) сразу после завершения периода весеннего половодья (рис. 8). Привлекает внимание важная роль щуки в формировании в этот период структуры рыбного населения практически всех исследован-

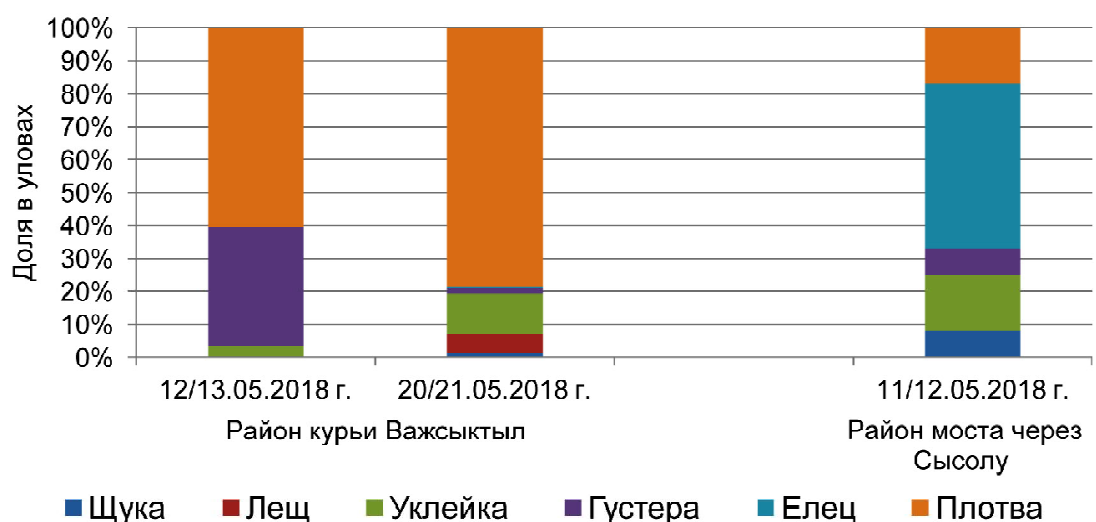

Рис. 5. Состав уловов рыбы на различных участках поймы р. Сысолы. Стандартный ряд сетей яч. 10-60 мм.

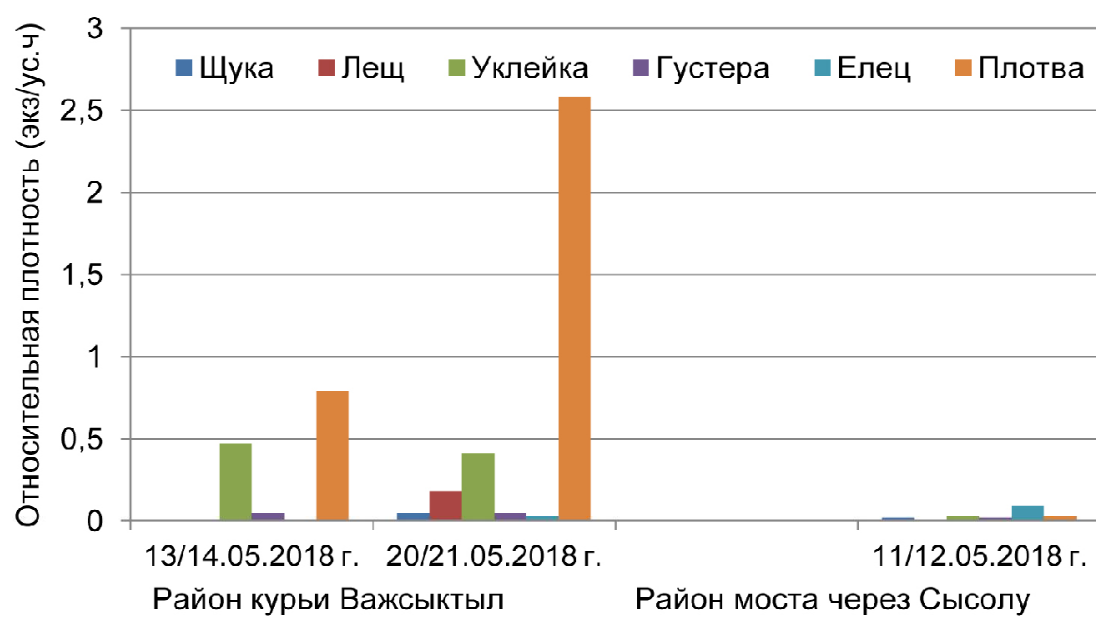

Рис. 6. Относительная плотность популяций рыб на различных участках поймы р. Сысолы.

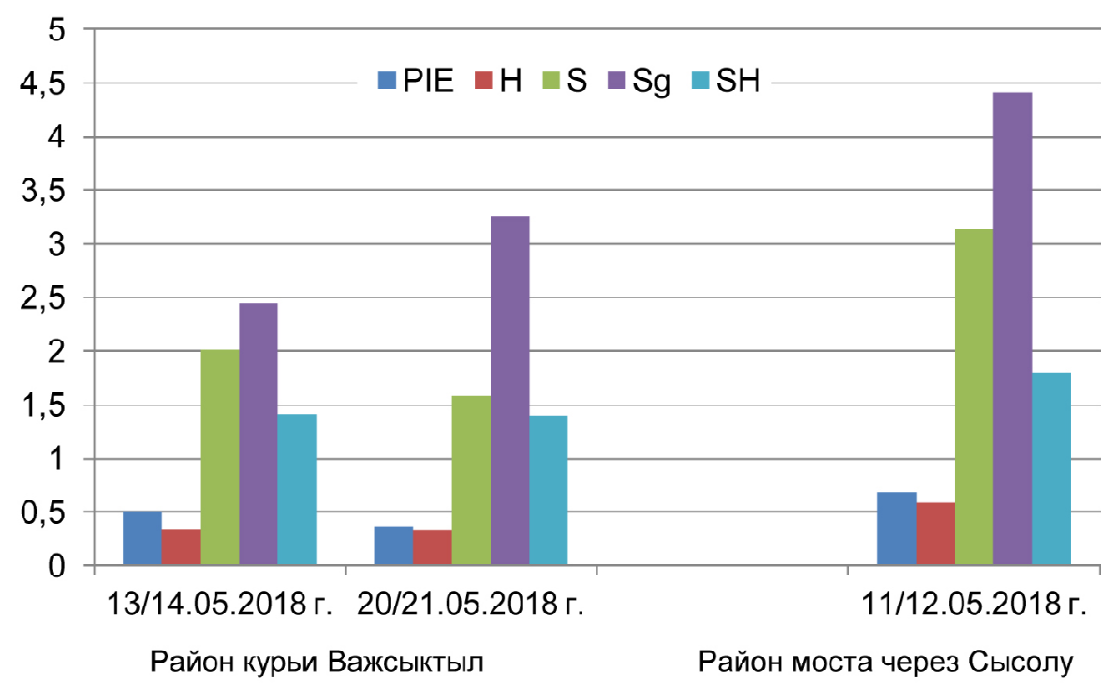

Рис. 7. Величина индексов разнообразия рыбного населения на различных участках поймы р. Сысолы. 


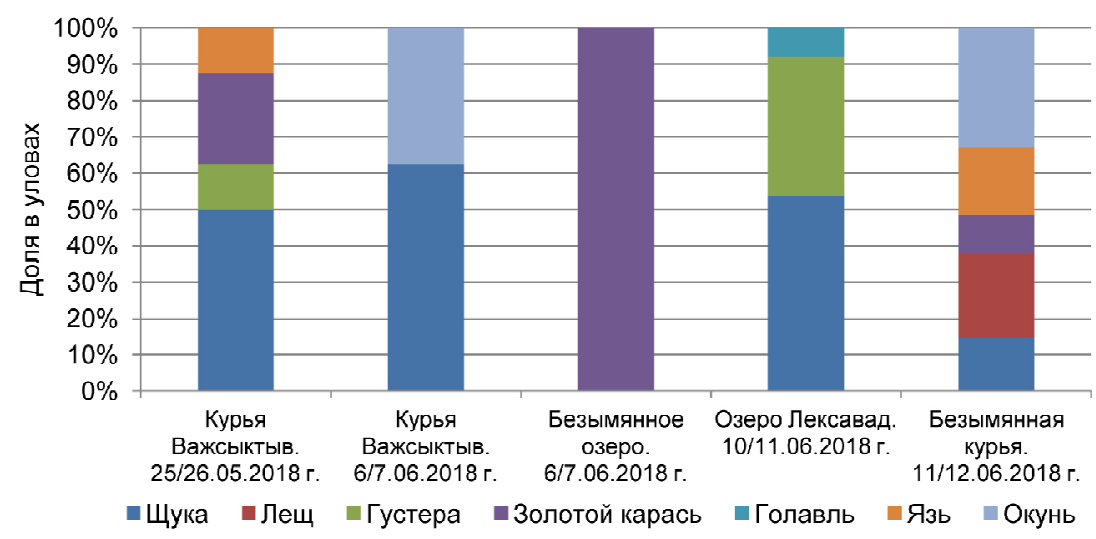

Рис. 8. Состав уловов рыбы в различных пойменных водоемах бассейна р. Сысолы. Сети яч. 30 мм.

ных пойменных водоемов, за исключением моновидового карасевого озера.

Общий набор встречающихся здесь в это время рыб составляет семь видов (включая единично встречаемого налима). При этом состав местного рыбного населения ни разу не дублируется, каждый водоем имеет присущие ему особенности набора обитающих здесь видов рыб. В обследованном районе не выявлено водоемов, в которых одновременно обитали бы все семь видов встреченных здесь рыб. Отсутствие в этих уловах уклейки и плотвы легко объяснимо размером ячеи использованных в данном случае сетей (30 мм).

На примере курьи Важсыктыл показано, что состав рыбного населения постоянных пойменных водоемов в период весеннего половодья значительно богаче, чем в летний период. В мае 2019 г. сетные уловы здесь включали девять видов рыб (щука, лещ, уклейка, золотой карась, густера, язь, плотва, налим и окунь), тогда как в период летней межени (середина августа) - только три (уклейка, густера и плотва, преимущественно молодь). Очевидно, это связано с использованием различными видами рыб в период весеннего половодья участков поймы для нереста и/или нагула.

В разные сезоны и годы исследований выборки щуки в курье Важсыктыл и на прилегающей залитой водой пойме (во время весеннего разлива) включали 10 возрастных групп от 2+ до 11+ лет. В контрольных уловах, произведенных в период половодья, здесь практически отсутствовали младшевозрастные особи (см. таблицу). Большинство составляли недавно отнерестившиеся и активно питающиеся рыбой и земноводными половозрелые производители щуки. В их рационе абсолютно преобладала плотва (до 20-30 экз. в желудочно-кишечном тракте одной щуки), но встречались и уклейки, окуни, налимы, миноги и, в ряде случаев, стрекозы.

Малочисленный в целом в период «большой воды» на пойме р. Сысолы лещ, в отличие от на- гуливающейся на разливах щуки, массово появляется на расположенных здесь нерестилищах перед нерестом, а по завершении икрометания вновь мигрирует в русло реки. Весь заходящий на нерест контингент леща состоит из достигших состояния функциональной половой зрелости особей и представлен преимущественно самцами (см. таблицу).

Не столько кратковременным, как в случае с лещем, представляется период пребывания на залитых пойменных лугах густеры, также нерестящейся здесь. В весеннее время ее уловы представлены старшевозрастными, преимущественно половозрелыми особями (см. таблицу).

Уклейка, нерестящаяся позднее большинства карповых рыб, постоянно живет в курье Важсыктыл, являясь в настоящее время одной из самых массовых видов рыб р. Сысолы. В период весеннего половодья на залитых пойменных лугах в 2018 г. нагуливались преимущественно не-

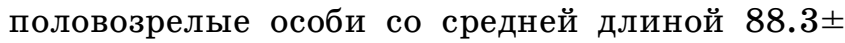
0.7 мм (пределы изменчивости 81-96 мм) и средней массой 6.6 \pm 0.2 г (соответственно 4-8 г). Нерест уклейки на данных участках поймы не отмечен, что можно объяснить ее видовыми предпочтениями к гидрологическим характеристикам водоемов.

Уловы язя включают преимущественно неполовозрелых особей, однако встречаются группировки, включающие и половозрелых рыб (см. таблицу). Судя по имеющимся материалам, нерест язя в данном районе происходит не ежегодно.

Биологические показатели одной из выборок ельца, отобранной в мае 2018 г., также представлены в таблице. Этот вид встречается на пойме Сысолы в районе курьи Важсыктыл небольшими стайками как на залитых лугах, так и в погруженных под воду кустарниках и участках притопленного леса.

Голавль в наших сборах присутствует единично. Выловлена исключительно молодь длиной 145-186 мм и массой 58-140 г, ее средний возраст соответствует 3.7 лет. Золотой карась также некрупный (см. таблицу); в возрасте $3+$ лет 57-97\% особей достигает функциональной половой зрелости.

Плотва представлена шестью возрастными группами (см. таблицу). Обращает внимание, что в бассейне р. Сысолы этот вид достигает массовой половой зрелости на третьем году жизни при длине менее 70 мм и массе 6-8 г. Ранее нами было установлено, что тугорослая форма плотвы из горного озера в бассейне р. Косью, расположен- 
Биологические показатели разных видов рыб поймы р. Сысолы в районе курьи Важсыктыл в период весеннего половодья

\begin{tabular}{|c|c|c|c|c|c|c|}
\hline $\begin{array}{l}\text { Возрастной } \\
\text { состав, лет }\end{array}$ & $\begin{array}{l}\text { Число рыб, } \\
\text { экз. }\end{array}$ & Длина, мм & Macca, г & $\begin{array}{c}\text { Доля } \\
\text { половозрелых, } \\
\%\end{array}$ & $\begin{array}{c}\text { Средний } \\
\text { возраст }\end{array}$ & $\begin{array}{c}\text { Соотношение } \\
\text { самцы:самки, \% }\end{array}$ \\
\hline \multicolumn{7}{|c|}{$\begin{array}{c}\text { Щука } \\
\text { Май } 2018 \text { г. }\end{array}$} \\
\hline $5+11+$ & 20 & $\frac{422.6 \pm 26.5}{286-663}$ & $\begin{array}{l}\frac{921.7 \pm 195.6}{238-3090} \\
\text { Май 2019 г. }\end{array}$ & 50 & 7.2 & $40: 60$ \\
\hline \multirow[t]{2}{*}{$4+-9+$} & 11 & $\frac{409.4 \pm 34.9}{278-583}$ & $\frac{821.0 \pm 205.8}{211-1912}$ & 64 & 6.3 & $45: 55$ \\
\hline & & & $\begin{array}{c}\text { Лещ } \\
\text { Май } 2018 \text { г. }\end{array}$ & & & \\
\hline $10+-15+$ & 12 & $\frac{360.8 \pm 8.5}{302-407}$ & $\frac{988.5 \pm 74.3}{541-1483}$ & 100 & 12.6 & $100: 0$ \\
\hline \multirow[t]{2}{*}{$7+-15+$} & 29 & $\frac{361.8 \pm 6.4}{293-440}$ & $\begin{array}{l}\text { Май } 2019 \text { г. } \\
\frac{977.5 \pm 52.3}{476-1609}\end{array}$ & 100 & 11.9 & $93: 7$ \\
\hline & & & $\begin{array}{c}\text { Густера } \\
\text { Май } 2015 \text { г. }\end{array}$ & & & \\
\hline $6+-9+$ & 36 & $\frac{121.8 \pm 3.8}{105-236}$ & $\frac{39.4 \pm 6.4}{22-251}$ & 89 & 7.0 & $44: 56$ \\
\hline \multirow[t]{2}{*}{$7+-9+$} & 9 & $\frac{167.9 \pm 8.9}{149-234}$ & $\begin{array}{l}\text { Май } 2019 \text { г. } \\
\frac{120.6 \pm 25}{76-314}\end{array}$ & 89 & 7.8 & $11: 89$ \\
\hline & & & $\begin{array}{c}\text { Язь } \\
\text { Май } 2018 \text { г. }\end{array}$ & & & \\
\hline \multirow[t]{2}{*}{$4+-9+$} & 5 & $\frac{227.4 \pm 26.1}{180-317}$ & $\frac{323.2 \pm 126.2}{132-789}$ & 40 & 5.2 & $40: 60$ \\
\hline & & & $\begin{array}{c}\text { Елец } \\
\text { Май } 2018 \text { г. }\end{array}$ & & & \\
\hline \multirow[t]{2}{*}{$5+-8+$} & 7 & $\frac{169.9 \pm 9.6}{118-194}$ & $\frac{84.1 \pm 12.5}{22-121}$ & 100 & 6.9 & $86: 14$ \\
\hline & \multicolumn{5}{|c|}{$\begin{array}{l}\text { Золотой карась } \\
\text { ое пойменное озеро в районе дер. Каргорт }\end{array}$} & \\
\hline \multirow[t]{2}{*}{$3+-5+$} & 83 & $\frac{101 \pm 0.9}{84-121}$ & $\frac{32 \pm 0.8}{20-53}$ & 80.7 & 3.7 & $68.7: 31.3$ \\
\hline & \multicolumn{5}{|c|}{ Июнь 2018 г. Безымянное пойменное озеро в районе курьи Важсыктыл } & \\
\hline \multirow[t]{2}{*}{$3+-6+$} & 42 & $\frac{138.8 \pm 2.3}{121-183}$ & $\frac{96,8 \pm 5.1}{61-219}$ & 98 & 3.2 & $52: 48$ \\
\hline & & & $\begin{array}{c}\text { Плотва } \\
\text { Май } 2018 \text { г. }\end{array}$ & & & \\
\hline $2+$ & 25 & $\frac{71.7 \pm 0.8}{64-81}$ & $\frac{5.6 \pm 0.2}{4-8}$ & 80 & - & $88: 12$ \\
\hline $4+$ & 2 & 103,129 & 17,36 & \multicolumn{3}{|c|}{ Половозрелые самец и самка } \\
\hline $5+$ & 2 & 111,132 & 26,34 & \multicolumn{3}{|c|}{ Половозрелые самки } \\
\hline $6+$ & 14 & $\frac{127.8 \pm 2.2}{116-144}$ & $\frac{40.6 \pm 2.2}{31-56}$ & 93 & - & 29:71 \\
\hline $7+$ & 2 & 135,148 & 38,58 & \multicolumn{3}{|c|}{ Половозрелые самцы } \\
\hline $8+$ & 1 & 177 & 116 & \multicolumn{3}{|c|}{ Половозрелая самка } \\
\hline \multirow[t]{2}{*}{$2+-8+$} & 46 & $\frac{98.2 \pm 4.6}{64-177}$ & $\frac{22.4 \pm 3.4}{4-116}$ & 87 & 3.8 & $63: 37$ \\
\hline & & & $\begin{array}{c}\text { Окунь } \\
\text { Май } 2015 \text { г. }\end{array}$ & & & \\
\hline $5+-8+$ & 15 & $\frac{138.2 \pm 4.6}{119-188}$ & $\frac{43.9 \pm 5.0}{28-104}$ & 20 & 6.5 & 7:93 \\
\hline $6+-8+$ & 29 & $\frac{188.6 \pm 2.5}{164-213}$ & $\begin{array}{l}\text { Май } 2019 \text { г. } \\
\frac{129.9 \pm 5.0}{88-187}\end{array}$ & 100 & 6.6 & $17: 83$ \\
\hline
\end{tabular}


ного на высоте 382 м над ур.м., созревает при сходных размерах, но на шестом году жизни (Пономарев, 2019).

В упомянутой работе выявленный факт рассматривался как пример перестройки обмена и преобладающего использования энергетических ресурсов в экстремальных условиях Приполярного Урала на генеративный обмен. В бассейне p. Сысолы одним из основных факторов, регулирующих воспроизводство местных видов рыб, является интенсивное нерегулируемое любительское рыболовство. Можно предположить, что мощный пресс рыболовства вызывает ответную реакцию популяции плотвы, ведущую к массовому половому созреванию в столь раннем возрасте и при размерах, которые могут указывать на формирование карликовой формы этого вида.

Биологические показатели окуня также охарактеризованы в таблице. Доля половозрелых особей сходных возрастных группировок в разные годы варьирует аналогично размерно-весовым показателям, однако в целом они соответствуют видовым. Это обстоятельство может свидетельствовать о том, что разные виды специфически реагируют на внешние воздействия, особую интенсивность среди которых в последние годы приобрело массовое нерегулируемое рыболовство.

\section{Заключение}

Таким образом, в результате впервые предпринятого исследования рыбного населения поймы р. Сысолы (на примере участка водосбора р. Сысолы в районе с. Ыб) установлено обитание здесь в период весеннего половодья 11 видов рыб: щуки, леща, уклейки, густеры, золотого карася, голавля, язя, ельца, плотвы, налима и окуня. Некоторые из этих видов, в частности, лещ, густера, карась, язь, плотва и окунь здесь нерестятся, тогда как остальные находят нагульные местообитания. Голавль и уклейка впервые отмечены для бассейна р. Сысолы.

Состав рыбного населения подвержен колебаниям в зависимости от уровня воды и в определенной степени корректируется временем нереста тех или иных видов. Столь же существенно изменяются плотность популяций массовых видов рыб, а также отображаемый информационными индексами уровень разнообразия рыбной части водного сообщества. Рыбное население постоянных пойменных водоемов в период весеннего половодья значительно разнообразнее, чем в период летней межени.

В условиях чрезвычайно интенсивного пресса нерегулируемого любительского рыболовства, в том числе и в период весеннего нереста, поддер- жание жизнеспособности популяций становится критически сложным для всех видов рыб. Важнейшим этапом индивидуального развития рыб является период воспроизводства, который для большинства видов бассейна р. Сысолы напрямую связан с поймой. В этой связи необходимо сосредоточение усилий природоохранных и контролирующих органов, региональных и муниципальных властей на сохранении пойменных водоемов и лугов, предотвращении добычи здесь торфа и других полезных ископаемых, запрете рубок леса, соблюдении правил любительского рыболовства и порядка особого режима водоохранных зон и прибрежных защитных полос.

Работа выполнена в рамках государственного задания по теме "Распространение, систематика и пространственная организация фауны и населения животных таежных и тундровых ландшафтов и экосистем европейского северо-востока России» № Гр. 04142018-0005.

\section{ЛИТЕРАТУРА}

Бознак, Э. И. Ихтиофауна реки Вычегды (морфология, биология, зоогеография) : автореф. дис. ... канд. биол. наук / Э. И. Бознак. - Санкт-Петербург : ГосНИОРХ, 2003. - 22 с.

Захаров, А.Б. Рыбное население водотоков Тимана / А. Б. Захаров, Э. И. Бознак. - Сыктывкар : ФИЦ Коми НЦ УрО РАН, 2019. - 184 с.

Зверева, О. С. Рыбные богатства Коми АССР и пути их освоения / О. С. Зверева, Е. С. Кучина, Л. Н. Соловкина. - Сыктывкар : Коми книжное издательство, 1955. - $106 \mathrm{c}$.

Кадастр особо охраняемых природных территорий Республики Коми / под ред. С. В. Дёгтевой и В. И. Пономарева. - Сыктывкар : Институт биологии Коми НЦ УрО РАН, 2014. - 428 c.

Пономарев, В. И. Распространение рыб в малых озерах горной полосы бассейна реки Косью (Приполярный Урал) / В. И. Пономарев // Вестник Пермского университета. Серия Биология. - 2019. - Вып. 2. C. 187-196.

Правдин, И. Ф. Руководство по изучению рыб (преимущественно пресноводных) / И. Ф. Правдин. Москва : Пищевая промышленность, 1966. - 376 с.

Рафиков, Р. Р. Формирование рыбного населения малых водохранилищ Республики Коми / Р. Р. Рафиков, А. П. Новоселов, А. Б. Захаров // Вестник Северного (Арктического) федерального университета. Серия: естественные науки. - 2015. - № 3. - С. 59-67.

Ресурсы поверхностных вод СССР. Т. 3. Северный край / под ред. И. М. Жила и Н. М. Алюшинской. Ленинград : 1972. - 664 с.

Соловкина, Л. Н. Рыбные ресурсы Коми АССР / Л. Н. Соловкина. - Сыктывкар : Коми книжное издательство, 1975. - 168 с.

Терещенко, В. Г. Оценка различных индексов для выражения биологического разнообразия сообщества / В. Г. Терещенко, Л. И. Терещенко, М. М. Сметанин // Биоразнообразие: Степень таксономической изученности. - Москва : Наука, 1994. - С. 86-98. 


\title{
THE STRUCTURE OF FISH COMMUNITY IN THE FLOODPLAIN OF THE MIDDLE REACHES OF THE SYSOLA RIVER IN SPRING FLOOD PERIODS
}

\author{
V.I. Ponomarev, N.P. Sokolova \\ Institute of Biology of Komi Scientific Centre of the Ural Branch of the Russian Academy of Sciences, Syktyvkar
}

Summary. The ichthyofauna of the Sysola River remains practically unstudied: there are only two publications dedicated to its research (Cadastre..., 2014; Rafikov et al., 2015). This paper aims at studying the structure of fish community in perennial impounded bodies and vernal ponds in spring flood periods in the context of a part of the Sysola River watershed in the Yb village area (Syktyvdinsky District, Republic of Komi). Field works were performed in 2015-2019. The composition of the local fish community was described. 11 fish species habitation was identified: pike, bream, bleak, white bream, crucian carp, chub, ide, dace, roach, burbot, and perch. Some fish species use the floodplain for spawning and feeding. The composition of the fish community depends considerably on water level in flood periods and its variations. At various times roach, bleak, white bream and perch predominate alternately. Equally considerable changes take place in the density of dominant fish species, as well as in the level of the diversity of the fish component of the aquatic community indicated by informational indices. The fish community of perennial impounded bodies is considerably more diverse in spring flood periods than in summer runoff low periods. Biological parameters of dominant fish species are presented, and some features of their biology are described. Under extremely intense pressure of unregulated recreational fishing, including spring spawning periods, it becomes critically difficult to maintain the viability of all fish species populations. Reproduction periods are the most critical stage of the fish ontogeny, and for most of the fish species in the Sysola River basin these periods are directly connected with the floodplain. It is necessary, therefore, to concentrate efforts of nature conservation bodies and supervisory agencies, regional and municipal authorities on conservation of floodplain water bodies and flood meadows, prevention of extraction of peat and other mineral resources and logging, as well as on scrupulous following special protection regime of water conservation zones and protected shoreline belts.

Key words: Sysola river, floodplain, oxbow, fish community, diversity, biological parameters 